\title{
The Role Of "Susu" A Traditional Informal Banking System In The Development Of Micro And Small Scale Enterprises (MSEs) In Ghana
}

Goski Alabi, Institute of Professional Studies, Legon, Accra, Ghana

Joshua Alabi, (E-mail: ipsdp05@yahoo.com), Institute of Professional Studies, Legon, Accra, Ghana

Stephen Tei Akrobo, Institute of Professional Studies, Legon, Accra, Ghana

\begin{abstract}
The paper examines the role of Susu a traditional banking system in the development of Micro and Small Enterprises (MSEs) in Ghana, using some selected MSEs and Susu operators. It combines both a reflective and empirical analysis approach. It is based on extensive review of literature on the subject and draws its conclusions from analysis of field data. It attempts to underscore the significance of Susu to MSEs in Ghana. The paper sought to ascertain the role of Susu in the development of MSEs by examining the effects of Susu on MSE development. The assessment was based on analysis of total turnover on investments, and number of people employed after five years of involvement in any Susu scheme. It also reviews the strengths, weaknesses and challenges of the system and offers some suggestions for strengthening it. The results of the study indicated that Susu generally contributes to the development of MSEs. However, the Susu systems favour the development of unorganized MSEs than organized MSEs. MSEs that do not rely on heavy capital outlay are more likely to succeed with Susu than those with heavy capital outlay. The study identifies self regulation as the major set back of the Susu scheme and recommends a system of regulation that may replicate the Ghana Credit Unions Association (GCUA) system.
\end{abstract}

Key Words: Susu, Microfinance, MSEs, Development

\section{INTRODUCTION}

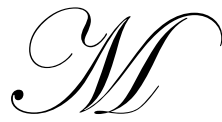

icro and Small Enterprises (MSEs) are commonly believed to have very limited access to deposits, credit facilities and other financial support services provided by Formal Financial Institutions (FFIs). This is because on one hand, these MSEs cannot provide the necessary collateral security demanded by these formal institutions and on the other hand, the banks find it difficult to recover the high cost involved in dealing with small firms. In addition to this, the associated risks involved in lending to MSEs make it unattractive to the banks to deal with such small enterprises (World Bank, 1994). Statistically, small enterprises are reported to have high failure rates making it difficult for lenders to assess accurately the viability of small enterprises, the abilities of the entrepreneur, and the likelihood of repayment. These are the most important criteria of creditworthiness applied by the banks (Ibid). Banks depend heavily on an entrepreneur's track record so when these are not available as in the case of MSEs, it becomes difficult to deal with such enterprises. Consequently, MSEs generally suffer serious economic deprivation as they strive hard to satisfy their basic business and financial needs. Many successful small enterprises have been reported to have had at least some access to bank finance and other forms of external finance. Other sources of support such as customers' advances and supplier's credit have also been mentioned to be at least as important as bank credit to many SMEs. Recent research results also suggests that though the demand for finance by small enterprises is less than is usually suggested by firm-level surveys, the 
demand is however more than the actual threshold that banks do accommodate. This brings to the fore the importance of informal financing, particularly micro-financing to the development of MSEs (World Bank, 1994).

In Ghana, only 5-6\% of the population is reported to have access to formal banking facilities (Basu et al., 2004). It has been reported that between 1998 to 1999, thirty nine percent (39\%) of Ghanaians borrowed money but only $3 \%$ of these people used formal institutions. (Claessens 2005). The lack of formal banking and credit facilities underpins the development of MSEs to a very large extent. This has serious implications for a country like Ghana where the economy is largely characterized by Micro and Small Scale Enterprises (MSEs). Though it has been suggested that there seem to be no evidence that SMEs alleviate poverty or decrease income inequality it has also been established that there is a strong association between the importance of SMEs and GDP per capita (Beck Et al, 2004). This suggests that MSEs development should be a matter of grave concern when considering issues of national development.

The frustrations of accessing credit facilities from formal financial systems compel the informal enterprises to resort to different non banking and informal arrangements to access funds for their business operations. Informal financial institutions operating outside the scope of banking laws and regulations in Ghana include Moneylenders, Rotating Savings and Credit Associations (ROSCA), and Savings Collectors. Both ROSCA and Susu Collectors commonly assist market traders, house wives and artisans to accumulate funds through daily or weekly deposits that are returned at the end of a specified period minus a small fee (World Bank, 1994). These activities are both based on the "Susu" system.

Susu is one of Africa's most ancient traditional banking systems which have over the years been the mode of fund mobilization for initiation, sustenance and in some cases development of MSEs, particularly micro enterprises. In Ghana, the word "Susu" is believed by some indigenous people to be Ga, a Ghanaian language, though some are of the view that it may be Akan another local Ghanaian Language. The system is reported to have originated from Yoruba, Nigeria where the 'Gas', a Ghanaian southern tribe is believed to have migrated from. Susu is an informal financial identification for daily or weekly deposit collection on the West African markets. "This Institution is ancient, dating back at least to the $16^{\text {th }}$ century, when Yoruba slaves carried it to the Caribbean, as part of their institutional luggage or social capital. Both the term 'Esusu; and the practice have persisted to this day, as Esu in the Bahamas, Susu in Tobago or Sou in Trinidad. Among the Yoruba in Nigeria today, it has been noted that there is hardly a single adult who is not a member of one or even several Esusu. (Seibel 2001: 3). The Institution exists all over West Africa as well as in many other parts of the world, where it is an integral part of the local micro-finance. With the expansion of the money economy, these informal financial institutions (IFIs) have not lost their vigor. Quite to the contrary, they have multiplied, both in numbers and diversity (Barclays 2005). The Susu system seems to have proven to be a dependable and cost effective mechanism of emphasizing state participation and encouragement of the domestic indigenous sector.

Susu can be described as a form of banking because it is a system of trading in money which involves safeguarding deposits and making the funds available to the owners when required or to borrowers at a fee. Susu can be considered a true banking system because historically, the essence of banking is to satisfy credit needs in business as Susu seeks to do. However, Susu is more than a financial product. It is also a social capital. As a social capital, the individual members derived mutual benefits from the network that cannot be achieved by isolated member efforts (De Souza Briggs, 1997). The Susu system has though, remained the purview of traditional groups and individuals for a long time and constitutes the crust of the informal microfinance system in Ghana. This system currently thrives on self regulation by operators. However, due to the perceived contributions of Susu to the development of MSEs, and its ability to mop excess liquidity through its savings mobilization methods, Susu is now being recognized and incorporated into some formal financial institutions as a deposit - loan system using Susu collectors (Basu et al 2004, Barclays Ghana 2005). The question is, does Susu really support MSE development in Ghana? 
The objective of this paper is to examine the role of Susu in the development of MSEs in Ghana using some selected MSEs, Susu Operators (SOs) ${ }^{1}$ and Formal Financial Institutions (FFIs). In doing this, the paper attempts to underscore the significance of Susu to the Micro and Small Enterprises in Ghana. The paper seeks to ascertain the effects of Susu on MSE development by assessing Total Turnover On Investment (TTOI) and number of people employed after five years of involvement in any Susu system in Ghana. It further seeks to ascertain the strengths, weakness and challenges of the system and finally to offer some suggestions for strengthening the system.

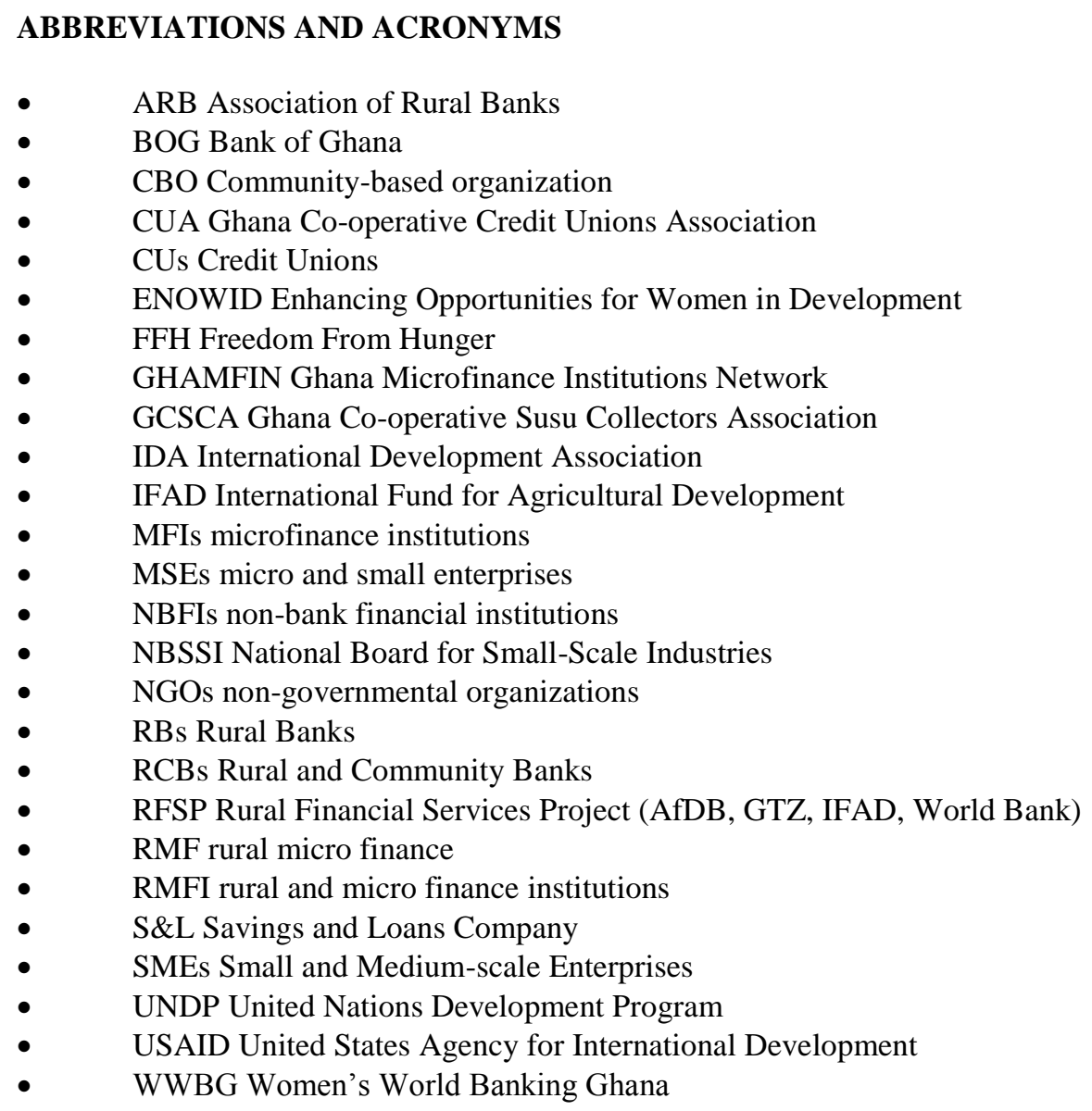

\section{OPERATIONAL DEFINITIONS}

The definition of MSEs in this study is founded on the classification of enterprises by the National Board for Small Scale Industries (NBSSI), The Ghana Enterprise Development Commission (GEDC), Ghana Statistical Survey, Industrial Statistics, and UNIDO's definition for developing countries. In this context, the definition for MSEs is based on the number of employees and Total Turnover on Investments (Kayanula and Quartey 2000, Elaian, K 1996, Steel and Webster 1990, Osei et al 1993). The definition takes into consideration some inherent weaknesses and arbitrariness in some of the definitions mentioned when they stand alone. By this classification, Micro-Enterprise employs less than 5 people with a total turnover of up to $\$ 10,000$ equivalent, Small Enterprises employ 5-19 people with a total turn over of between $\$ 10,000$ - \$100,000 equivalent and Medium Enterprises

\footnotetext{
${ }^{1}$ There are three categories of Susu Operators (SOs), these are: Susu Collectors (Individuals or Companies), Rotating Savings and Credit Associations (ROSCA) and Susu Clubs
} 
employ 20 to 100 people with an annual turn over of above $\$ 100,000$. Ekumah and Essel had also used a similar categorization in their 2003 IMF working paper. (Kayanula and Quartey 2000: 9, Ekumah and Essel 2003: 23).

MSEs have further been classified into two categories, 'organised' and 'unorganised' enterprises. The organized MSEs 'are those with paid employees and a registered office and Unorganized MSEs are mainly made up of artisans who work in open spaces, temporary wooden structures, or at home and employ little or in some cases no salaried workers. They rely mostly on family members or apprentices'. (Kayanula Quartey, 2000, Liedholm \& Mead, 1987; Osei et al, 1993, World Bank, 1992; Gray, Cooley \& Lutabingwa, 1997)

The operational definition for Total Turnover on Investment (TTOI) is the change between the present value of total revenue an enterprise generates from its investments in assets and the total revenue at the time of joining any Susu scheme.

TTOI $=\quad \frac{\underline{\mathrm{T}}_{5}-\underline{\mathrm{T}}_{0}}{\mathrm{~A} 5-\mathrm{A} 0}$

Where $\quad T_{0}$ is the average sales at the point of joining any Susu Scheme

$\mathrm{T}_{5}$ is the average sales after five years joining any Susu Scheme

$\mathrm{A}_{0}$ is total investment at the point of joining any Susu Scheme

$\mathrm{A}_{5}$ is total investment after five years of joining any Susu Scheme

\section{METHODOLOGY}

The methodology was based on a cross- sectional survey method with three (3) main components. These included Reviews, Contacts and Field Activities. The review was conducted through desk research of online resources, research papers, working documents, conference documents, and other publications. The contacts were made through one on one discussion and/or small group discussions by visiting offices and officials of banks involved in the Susu system whether, semi informal or formal. A self developed instrument was used for the field exercise. The study classified the Susu system into three categories based on the classification by Basu et al., 2004 in an IMF working paper. These are Susu Clubs and Susu Associations, ${ }^{2}$ Mobile Collectors ${ }^{3}$, and Cooperatives ${ }^{4}$. The sample design was based on a multi-phase sampling approach. The Ghana Cooperative Susu Collectors Association (GCSCA) was contacted for their membership list. A purposive sample of each category was drawn based on judgment sampling. The sample frame for the Susu Operators was made up of:

- 5 Susu Clubs and Associations

- $\quad 10$ Mobile collectors

- 5 Susu cooperatives

Lists of contributors (MSEs) that have contributed to Susu for at least five years were compiled from the selected Susu Operators. The lists were first stratified into organized and unorganized MSEs and then the systematic sampling technique used to draw the test sample from the list of contributors (MSEs). A follow-up was then made to interact with Contributors using the self developed questionnaire. Both the organized and unorganized MSEs were sampled from five communities in Accra, namely: East Legon, Kaneshie, Nungua, Madina and Abokobi representing urban affluent, peri-urban, urban poor and rural settings.

\footnotetext{
${ }^{2}$ Offer a savings vehicle by collecting daily amounts voluntarily saved by their clients, which they return at the end of the month minus one day's amount as commission.

${ }^{3}$ These are (a) Associations: either rotating savings and credits Associations (ROSCAs) that collect savings from their members and allocate them to each member in turn, or accumulating which allows regular contributions to the accumulated to act as a back up or insurance for special events like funerals, etc. (b) Clubs: this combines the first two concepts, operated by a single agent. Members commit to save a pre-defined amount over a medium term (50 to 100 week cycle) and pay commissions on each payment and fees when they are advanced the targeted amount before the end of the cycle. (Basu et al 2004:9)

${ }^{4}$ These are credit unions and cooperatives which have employed the Susu concept.
} 
- $\quad$ Group 1: Organized SMEs

SMEs with paid employees and a registered office

- $\quad$ Group 2: Unorganized SMEs

Mainly made up of artisans who work in open spaces, temporary wooden structures, or at home and employ little or in some cases no salaried workers. They rely mostly on family members or apprentices.

\section{STUDY TOOLS}

The survey tool was semi structured and included questions covering number of years of involvement in any Susu scheme, source of initial capital, total turnover on investments before and after joining any Susu scheme ${ }^{5}$, sources of the working capital, and number of employees before and after joining Susu for at least five years and whether Susu is the sole source of fund mobilization or savings. The tool also sought to ascertain how Susu has contributed to the growth of their business based on number of employees and Total Turnover on Investment. (Refer to Appendix C)

\section{Assumptions Of The Study}

The study is based on the following Assumptions

- $\quad$ That increases in number of employees reflects growth of an MSE

- That increases in Total Turnover on Investment reflects growth

- $\quad$ That these parameters can be assesses quantitatively and accurately

\section{Analysis Of Data}

The paired observation test was used to analyze the data and to ascertain the relationship between involvement in any Susu scheme for at least five years and the development of MSEs in terms of changes in number of people employed and changes in total turnover on investment.

\section{RESULTS OF THE STUDY}

A total of 101 MSEs were interviewed. These included forty one (41) organized and 60 unorganized MSEs mainly traders, service providers, artisans and vocational business operators. In addition the Ghana Cooperative Susu Collectors Association (GCSCA) and four banks were visited to collect data.

The biggest challenge encountered in gathering and analyzing the data for this study was the lack of adequate book keeping records and knowledge of financial accountability by MSEs. Ascertaining increase in number of employees was however more reliable than the total turnover. The study set out to measure the differences in annual turn over, but the difficulties encountered during pre-testing of the study tool resulted in modifying the study indicator to total turn over on investment.

The results are categorized into three:

- $\quad$ Sources of initial and working capital

- $\quad$ Analysis of changes in number of employees and total turnover on investment

- Interviews of MSEs and financial institution

\footnotetext{
${ }^{5}$ Total turnover on investment is the working capital at the time of the survey.
} 


\section{Sources Of Initial And Working Capital}

Table 1: Sources of Initial and Working Capital by MSEs

\begin{tabular}{|c|c|c|c|c|}
\hline \multirow{2}{*}{ Sources } & \multicolumn{2}{|c|}{ Source of Initial Capital } & \multicolumn{2}{c|}{ Source of Working Capital } \\
\cline { 2 - 5 } & Organized MSEs & Unorganized MSEs & Organized MSEs & Unorganized MSEs \\
\hline Own Savings (Susu) & 17 & 32 & 20 & 38 \\
\hline Relations & 16 & 23 & 7 & 3 \\
\hline Bank Loan & 4 & 0 & 3 & 6 \\
\hline Suppliers Credit & 3 & 2 & 11 & 17 \\
\hline Profits & na & na & 25 & 46 \\
\hline Customer Advances & 4 & 6 & 5 & 8 \\
\hline
\end{tabular}

Source: Study results

\section{ANALYSIS OF DATA}

\section{Changes In Number Of Employees And Total Turnover On Investment}

1. Analysis of composite Data (for both organized and unorganized MSMEs)

$\mathbf{H}_{\mathbf{0}}$ : The change in number of employees and total turnover on investment after 5 years of Susu contribution is not significantly different

$\mathbf{H}_{1}$ The changes in both the number of employees and total turnover on investment after five years of Susu is significantly different.

Table 2: Analysis of changes in number of employees and total turn over of MSMEs (Paired Observation Test)

\begin{tabular}{|c|c|c|c|c|c|c|}
\hline Study Variable & $\begin{array}{c}\text { Number of } \\
\text { Respondents }\end{array}$ & $\begin{array}{c}\text { Mean } \\
\text { Difference }\end{array}$ & $\begin{array}{c}\text { Standard } \\
\text { Deviation }\end{array}$ & $\begin{array}{c}\text { Standard } \\
\text { Error }\end{array}$ & $\begin{array}{c}\text { Test } \\
\text { Statistics }\end{array}$ & $\begin{array}{c}\text { critical } \\
\text { values }\end{array}$ \\
\hline $\begin{array}{c}\text { Changes in number } \\
\text { of employees }\end{array}$ & 97 & 2.247 & 2.031168218 & 0.2062332 & 10.897481 & 2.33 \\
\hline $\begin{array}{c}\text { changes in total } \\
\text { turnover }\end{array}$ & 101 & $3,972,489.505$ & 12866078.15 & 1280334.2 & 3.1026974 & 2.33 \\
\hline
\end{tabular}

Source: Survey Results

From the paired observation test, the test statistic for changes in number of employees is 10.897 which is greater than the critical 2.33 hence we fail to accept the null hypothesis at $1 \%$ level of significance and the test statistic of total turn over, 3.102 is greater than the critical 2.33. Since the test statistics is greater than the critical we fail to accept the $\mathrm{H}_{0}$, which suggest that within the limits of all errors encountered there is enough evidence to suggest that the change in the total Turnover on Investment of MSEs is significant. Therefore it can be suggested that there is a supportive relationship between the involvement of Susu and MSE development in Ghana.

2. Analysis of Differentials

- $\quad$ Organized MSMEs 
Table 3: Analysis of Changes in Number of Employees and Total Turnover of Organized MSEs (Paired Observation Test)

\begin{tabular}{|c|c|c|c|c|c|c|}
\hline Study Variable & $\begin{array}{c}\text { Number of } \\
\text { Respondents }\end{array}$ & $\begin{array}{c}\text { Mean } \\
\text { Difference }\end{array}$ & $\begin{array}{c}\text { Standard } \\
\text { Deviation }\end{array}$ & $\begin{array}{c}\text { Standard } \\
\text { Error }\end{array}$ & $\begin{array}{c}\text { Test } \\
\text { Statistics }\end{array}$ & $\begin{array}{c}\text { critical } \\
\text { values }\end{array}$ \\
\hline $\begin{array}{c}\text { Changes in number } \\
\text { of employees }\end{array}$ & 32 & 1.688 & 1.654661061 & 0.2925032 & 5.7691687 & 2.33 \\
\hline $\begin{array}{c}\text { changes in total } \\
\text { turnover }\end{array}$ & 36 & $1,223,301.389$ & 5846297.564 & 974382.93 & 1.2554627 & 2.33 \\
\hline
\end{tabular}

Source: Survey Results

From the paired observation test, the test statistic for changes in number of employees is 5.769 which is greater than the critical 2.33 . Hence we fail to accept the null hypothesis at $1 \%$ level of significance. For total turn over on investment the test statistic, 1.255 is less than the critical 2.33. Since the test statistics is less than the critical we fail to reject the $\mathrm{H}_{0}$, which suggest that within the limits of all errors encountered there is enough evidence to suggest that the change in the total return on investment of organized MSEs is not statistically significant after five years of involvement in any Susu system. This could point to the fact that organized SMEs are likely to be employing more people than may be required. This together with other overhead cost may lead to higher operational cost resulting in the insignificant change in turnover over the period under consideration.

\section{Unorganized MSEs}

Table 3: Analysis of Changes in Number of Employees and Total Turnover of Unorganized MSEs (Paired Observation Test)

\begin{tabular}{|c|c|c|c|c|c|c|}
\hline Study Variable & $\begin{array}{c}\text { Number of } \\
\text { Respondents }\end{array}$ & $\begin{array}{c}\text { Mean } \\
\text { Difference }\end{array}$ & $\begin{array}{c}\text { Standard } \\
\text { Deviation }\end{array}$ & $\begin{array}{c}\text { Standard } \\
\text { Error }\end{array}$ & $\begin{array}{c}\text { Test } \\
\text { Statistics }\end{array}$ & $\begin{array}{c}\text { critical } \\
\text { values }\end{array}$ \\
\hline $\begin{array}{c}\text { Changes in number } \\
\text { of employees }\end{array}$ & 65 & 2.523 & 2.151363611 & 0.2668524 & 9.4549550 & 2.33 \\
\hline $\begin{array}{c}\text { changes in total } \\
\text { turnover }\end{array}$ & 65 & $5,495,116.769$ & 15275869.45 & 1894728.5 & 2.9002133 & 2.33 \\
\hline
\end{tabular}

Source: Survey Results

From the paired observation test statistic, 9.455 is greater than the critical 2.33 therefore we fail to accept the $\mathrm{H}_{0}$, which suggest that within the limits of all errors encountered there is enough evidence to suggest that there is a significant difference in change in number of employees after five years of involvement in any Susu system.

From the paired observation test statistic, 2.900 is greater than the critical 2.33 , therefore we fail to accept the $\mathrm{H}_{0}$. This suggest that within the limits of all errors encountered in the study, there is enough evidence to suggest that there is a significant difference in total turn over on investment though to a lesser extent in comparism to the change in number of employees after at least five years of involvement in any Susu system.

\section{Discussion Of Results}

Analysis of the results of the study suggests that, most MSEs rely on Susu through personal savings and remittances from relations to start their businesses. About eighty - two percent (82\%) of MSEs relied on both Susu and remittances from relations. This was made up of Susu $46 \%$ and relations support 36\%. Customer advances constituted 9.34\%, Suppliers' credit 4.7\% while Bank loans constituted only $3.73 \%$ as source of initial capital. This makes Susu the single largest contributor as source of initial capital. Susu and profit injection were the main sources of working capital constituting about $68.3 \%$ of working capital though here profits contributed a little more than Susu. The Study brought to the fore that though Susu generally contributes to the development of Micro and Small 
Scale Enterprises in Ghana, its role in creating income stability, employment and growth is statistically questionable for organized MSMEs. However it seems to remain an effective means of raising initial capital and for sustaining most MSEs through weekly contributions to ROSCA and Susu clubs with a few bank interventions.

Generally, there was a significant change in the number of employees and total turnover on investment for MSEs involved in any Susu scheme for at least five years. However, the difference in turnover observed was accounted for largely by the unorganized MSEs. This is because while the changes in both the number of employees and total turnover on investment for the unorganized MSEs were statistically significant, it was not the same in the case of the organized MSEs. In the case of the organized MSEs, analysis of data revealed that though there was a significant change in the number of employees, the corresponding change in total turnover on investment was not significant. This raises a number of questions. Could this factor contribute to the reasons why most SMEs normally collapse after five years?

The analysis of data supports the view that even though the MSEs sector is labour intensive and employs more people per unit of capital than larger enterprises, the job creating impact can be said to be a statistical flaw. The results of this study suggest that increases in employment created by MSEs may not often be associated by increases in productivity particularly for organized MSEs. This was made evident by the analysis of data, which clearly indicated that though increases in number of employees of organized MSEs involved in any Susu system for at least five years were statistically significant, the total turnover of the organized MSEs over the same period were not significant. This implies that the increases in productivity were not significant whereas, the number of employees were. The results therefore, pointed to the fact that organized MSEs may actually be employing more than they actually require or in addition may not be making efficient use of scarce resources as is sometimes believed.

In addition, though changes in both employees and total turn over on investment were significant for unorganized MSEs, in reality the job creating effects of MSEs in general can be said to be virtually less significant. This is because unorganized MSEs rely on unpaid services from either family relations or apprentices. They therefore do not offer real employment to those that they engage aside the entrepreneurs' themselves. Most of these unorganized MSEs do not fully pay for some of the factors of production, wages, rent and tax. It must be noted that about sixty percent $(60 \%)$ of the MSEs involved in this survey were unorganized and this affected the overall significance of both changes in numbers of employees and the total turnover on investment for the composite analysis. Labour productivity seems to be lower in organized MSEs than unorganized. This supports the theory of negative marginal returns. Here, organized MSEs no matter how small fill out the organizational chart with the required labour. As more and more labour is employed the return on investment dwindles. In addition, organized MSEs have to pay for all the other factors of production, rent, wages and tax aside the enterprises contrary to this case of unorganized MSEs. This stretches and puts the real economic capabilities of the organized MSEs on the line resulting in a dwindling effect on their capital holdings. Though other research results suggests that capital productivity is higher in SMEs than in LSEs, the results of this study points to the fact that this is still not enough to sustain the growth of MSEs and therefore impact significantly on the development of MSEs. This challenges earlier observations that capital productivity is higher in small enterprises than larger ones. Available data indicate that even though the private sector which is basically dominated by MSEs accounts for more than eighty percent of employment, it constitutes only about forty percent of the Gross National Income (GNI). This supports the evidence of mismatch between increase in number of employees created by Susu dependent MSEs and increases in total turnover on investment. Thus, all things being equal, for the MSE sector in Ghana to create more employment opportunities, which would lead to income stability and a more equitable distribution of income, other conditions should prevail. These should include training in basic business management skills, availability and access to capital, cost of capital, low inflation and favorable government policies.

\section{Other Latent Strengths Of Susu}

Aside being a financial capital, Susu also serves as a strong social capital base which is an incentive to most members. The benefits derived from the networks of people working together as in the most prominent Susu schemes (the ROSCA and Susu Clubs cannot be compensated for by the formal banking institutions. These are 
beneficial packages that formal and semi-informal banking and financial systems cannot offer their clients and therefore may not be able to compete with the Susu system over such clients. As part of the focus on customers, Susu does not only deliver the service at the comfort zone of its clients, it serves as a meeting place for clients to socialize weekly or periodically and as and when required. Susu in real concrete situations has gone beyond a financial product to a welfare product where individual members of the group have a sense of belonging and support.

The welfare aspect of Susu in effect is an additional product for the contributors and therefore gives these operatives a competitive advantage within the target group over the traditional banking institutions. In addition, Susu has quite an effective mechanism of "Know Your Customers system" (KYC), which probably cannot be replicated by formal systems. This reduces the inherent risks and hazards of clean lending because it does not require any collateral. The Susu system for KYC cannot at the moment be easily replicated by the formal banking institutions. This is because the formal systems for KYC in Ghana, is poor due to inadequate infrastructure in terms of the address system, street naming system, house numbering and the national identification system, which are either lacking or even when available not reliable. This makes it really difficult for banks to identify and trace clean lending customers when the customer's location changes. Interviews conducted with bank staff in this study, revealed that this weakness has been exploited by some staff in some of the banks that introduced the Susu system or clean lending system and it is one of the biggest challenges in trying to integrate Susu into the formal banking system. One bank officer remarked "some officers tend to manipulate these limitations for personal gains. It is known that the KYC policy or system is poor and weak so it is easy for one to say, I can not trace a customer and after a period the bank would have to write it off as bad debt. This coupled with the relatively high incidence of customer disappearances have not made micro- finance attractive enough for investors. Banks as a result now prefer to deal with a Susu-Representative, so that that person interfaces between the bank and the numerous customers. The Susu operatives have their own traditional ways of knowing their customers and employ all manner of traditional mechanisms to insure clean lending (no collateral) which, the bank cannot replicate. Entrusting things in the hands of the Susu operators have been satisfactory. This reduces the inherent hazards and risks associated with clean lending though relatively marginally'.

\section{WEAKNESSES OF THE SUSU SYSTEM}

Most of the Weaknesses are inherent in the self regulatory nature. It is therefore recommended that:

Appropriate laws, rules and regulations be enacted to control the Modus Operandi of the Susu schemes in order to sustain and maximize it potential in Ghana. The collectors must be insured to regulate their operations. This would weed out fraudulent individuals who may want to defraud the vulnerable, such as the illiterates and less educated members of the scheme

To mitigate the obstacles of irregular payments by contributors and loan delinquency, Susu agents could be involved in appraising customers and recovering loans. The National Medium Term Private Sector Development Strategy should adequately cater for the regularization and strengthening of the Susu system in its implementation. It is believed that with adequate training in book keeping and basic entrepreneurial skill and regulation, Susu could tend the informal financial sector round and contribute effectively to the development of private sector which is believed to be the engine of growth of Ghana's economy

\section{CONCLUSIONS}

The study though not conclusive in itself, suggests that involvement in Susu generally has a relationship with MSEs development in Ghana. The study further suggests that among other factors, Susu presence contributes favourably to the development of MSEs in Ghana. However, Susu favours the development of unorganized MSEs than organized. Generally Susu contributes to fund mobilization and cash injection into MSEs and acts as a form of insurance for most of these businesses. Though not conclusive enough, the study again suggests that Susu does not favour the development of organized MSEs. Statistically, there seem to be some evidence to suggest that MSEs that 
succeed with Susu are the unorganized ones. MSEs that do not rely on heavy capital outlay are more likely to succeed with Susu than those with heavy capital outlay.

In addition, the study concludes that, Susu is more than a financial product. It is also a social capital. It performs other useful roles in ensuring social and income stability, growth and employment particularly to entrepreneurs of unorganized micro and small enterprises. However such roles in the development of small to medium and organized MSEs, which offer real employment to its members not only the entrepreneurs, seem limiting. The study therefore supports the view that the job creating impact of MSEs is statistically defective. The study also deduced that in searching for answers to the perennial problem of financing MSEs, Susu could be a suitable option if well recognized and regulated. However, this study further implies that the developmental needs and well being of MSEs go far beyond micro finance.

The study also concludes that the savings mobilizations and credits methods of Susu cannot be easily replicated by the formal system but can be adapted.

\section{RECOMMENDATIONS}

In the light of the foregoing conclusions of the study, it may be suggested that:

1. Policy makers consider regulating the sector, by enacting appropriate laws, rules and regulations which would control the Modus Operandi of the Susu schemes and also to sustain them.

2. Collectors must be insured to regulate their operations. Here, lessons can be learnt from the Credit Union Scheme and GCCUA system. This would weed out fraudulent individuals who may want to defraud the vulnerable, such as the illiterates and less educated members of the scheme.

3. To mitigate the obstacles of irregular payments by contributors and loan delinquency, Susu agents could be involved in appraising customers and recovering loans. In this case a short training in accounting, book keeping and basic business management principles should become a pre-requisite for accepting MSEs into the ROSCA and Susu clubs since this is where the loan delinquency rate seems higher. To improve on the capacity of Susu operators for appraisal, training should be offered to them in this regard.

4. Microfinance interventions in general must be tied with basic management training, quality management training and basic accounting skills. Here the basic requirement for an MSE to access micro finance should not be collateral or merely a form of guarantee but ability to groom the enterprise.

\section{REFERENCE}

1. Amankwah A, 2007, Ghana: Country to Develop Micro Finance Policy, Public Agenda $4^{\text {th }}$ April, 2007, Acrra, \& U.G. Damachi, 1982: Self-Help Organizations: Guidelines and Case Studies for Development Planners and Field Workers - a Participative Approach. Bonn, Friedrich-Ebert-Stiftung

2. Andah D, 2005, Regulation, Supervision, and Access to Microfinance: The Case of Ghana Essays on Regulation and Supervision No. 10.

3. Anheier H.K and Seibel H.D (1987), Small Scale Industries and Economic Development in Ghana, Business Behaviour and Strategies in Informal Sector Economies, Verlag Breitenbech, Saarbruckh, Germany.

4. Ayertey, E. (1998). Informal Finance Prepared for Private Sector Development in Africa. (Background paper prepared for African Development Report

5. Aryeetey E, et al. (1994), Supply and Demand for Finance of Small Scale Enterprises in Ghana, World Bank Discussion Paper No. 251 Banking Law 1989 PBDCL 225. As amended by banking Act of 2004, Financial Institutions (Non-Banking Law 1993, PNDCL 328)

6. Aryeetey E, Hettige H, Nissanke M \& Steel W (1997), Financial Market Fragmentation and Reforms in Ghana, Malawi, Nigeria, \& Tanzania, The World Bank Economic Review, Vol. 11 No. 2 PP 195-218.

7. Bartels K, 2003, Press Briefing, by private sector Development, conference room, ministry of information, $15^{\text {th }}$ July 
8. Basu A, Blavy R, and Yulek M, 2004, Microfinance in Africa: Experience and Lessons from IMF International Monetary Fund

9. Bienpou F, 2004, Group Intermediation in Ghana. The Credit with Education Programme: A case study, London, UK: Alternative Finance, www.alternative-finance.org.uk

10. CIA 2006, Ghana Economy, World Factbook, http://www.theodora.com/wfbcurrent/ghana/ghana_economy.html

11. Chen, M.: Women in the Informal Sector: A Global Picture, the Global Movement. SAIS Review, Winter Spring 2001

12. Claessens, Stijn, 2005, Access to Financial Services: A Review of the Issues and Public Policy, World Bank Policy Research Working Paper No. 3589. Available at SSRN: http://ssrn.com/abstract=744644

13. Daniels, L and Ngwira A. (1993), Results of a Nation-wide Survey on Micro, Small and Medium Enterprises in Malawi, GEMINI Technical Report No 53. PACT Publications, New York.

14. Daniels \& Fisseha (1992), Micro and Small Scale Enterprises in Botswana: Results of a Nation-wide Survey, Gemini Technical Report No. 46, Washington D.C, Development Alternatives Inc.

15. Dawson J (1990), The Wider Context: The Importance of The Macroenvironment for Small Enterprise Development, Small Enterprise Development, Vol. 1 No. 3

16. De Souza Briggs, X. (1997), Social Capital and the cities: advice to change agents. National Civic Review, 86 (2, summer ), 111- 118

17. Ekumah, E.K. and Essel T. (2003). Information is Power: the Problem with Credit Accessibility in Rural Banks in Ghana.

18. Elaian, K (1996), Employment implications of small scale industries in developing countries: evidence from Jordan, Science, Technology and Development, 14(1).

19. Fisseha and McPherson (1991), A Country-wide Study of Small Scale Enterprises in Swaziland, Gemini Technical Report No. 24, Washington D.C: Development Alternatives Inc Steel,

20. Heintz J, 2005, Elements of an Employment Framework For Poverty Reduction in Ghana Report of a joint ILO/UNDP mission, Political Economy Research Institute, University of Massachusetts, Amherst

21. Ghana Statistical Services, GSS, (2000a), Ghana Living Standards Survey: report of the fourth round (GLSS 4), Accra.

22. Ghana Statistical Services, GSS, (2000b), Poverty Trends in Ghana in the 1990s, Accra.

23. Government of Ghana (2003), Ghana Poverty Reduction Strategy 2003-2005: an Agenda for Growth and Prosperity, Accra, Ghana.

24. Ghana Living Standards Survey: Report of the Fourth Round (GLSS 4). Ghana Statistical Service, October 2000.

25. Gokcekus et al 2001, Human Capital and Efficiency: The Role of Education and Experience in MicroEnterprises of Ghana's Wood-Products Industry, Journal Of Economic Development Volume 26, Number 1 , June 2001

26. Gilles G. \& Issa B. (1999) The role and impact of savings mobilization in West Africa: A study of the informal and Intermediary financial sectors, Volume II

27. Jone $\mathrm{H}$ et al, 2000, Linking Formal And Informal Financial Intermediaries In Ghana: Conditions For Success And Implicatons For Development Number 61, November 2000

28. Liedholm C and Mead D (1987), Small Scale Industries in Developing Countries: Empirical Evidence and Policy Implications', International Development, Paper No.9, Dept of Agricultural Economics, Michigan State University, East Lansing, MI, USA.

29. Mbai B, Akwasi-Kuma J, UNDP Microfinance Assessment Report Prepared as a component of the MicroStart Feasibility Mission - September, 1997

30. Mead \& Liedholm (1998) The Dynamics of Micro and Small Enterprises in Developing Countries', World Development Vol. 26 No. 1

31. Mosley P \& Hulme D (1998), Microenterprise Finance: Is There a Conflict Between Growth and Poverty Alleviation?, World Development Vol. 26, No.5, PP 783-790.

32. Mwanakatwe M, 2005, Barclays Bank of Ghana Limited Launches Microbanking, Accra

33. Nikoi G, 1995, Change Agents in the Development of Financial Services for Small-Scale Enterprises in Ghana, ed. Edited by Philip English and Georges Hénault, the International Development esearch Centre, Ottawa, Canada 
34. Osei B, Baah-Nuakoh A, Tutu K.A, \& Sowa N.K (1993), Impact of Structural Adjustment on Small-Scale Enterprises in Ghana, in Helmsing A.H.J and Kolstee T. H(eds), Structural Adjustment, Financial Policy and Assistance Programmes in Africa, IT Publications.

35. Schmitz Hubert (1995), Collective Efficiency: Growth Path for Small Scale Industry, The Journal of Development Studies, Vol. 31 No. 4 PP 529-566.

36. Steel and Webster L (1990), Ghana's Small Enterprise Sector: 'Survey of Adjustment Response \& Constraints, Industry Series Paper 41, World Bank, Industry and Energy Dept, Washington D.C

37. Steel W.F (1977), Small Scale Employment and Production in Developing Countries Evidence from Ghana, Praeger,New York, USA.

38. Steel W.F. and D.O. Andah 2004, Implications for Development and Performance, Report for Industry, International Conference on Ghana at Half Century pp. 9

39. Seibel, H.D, \& U.G. Damachi, 1982: Self-Help Organizations: Guidelines and Case Studies for Development Planners and Field Workers - a Participative Approach. Bonn, Friedrich-Ebert-Stiftung.

40. Seiel H. D, 2001, Mainstreaming Informal Financial Institutions Journal of Developmental Entrepreneurship vol. 6 no. 1 (April 2001): 83-95

41. The World Bank \& IFAD, 2000: Ghana - Rural Financial Services Project. Washington DC \& Rome

42. Robson G \& Gallagher C (1993), The Job Creation Effects of Small and Large Firm Interaction, International Small Business Journal, Vol. 12 PP 23-37.

43. UNIDO, (1983), The Potential for Resource-based Industrial Development in the Least Developed Countries, No.5-Malawi.

44. World Bank,1992, Malawi: Financial Sector Study, Washington D.C

45. Wynarczyk P, Watson R, Storey D.J, Short H \& Keasey K (1993), The Managerial Labour Market in Small \& Medium Sized Enterprises, Routledge, London. 


\section{APPENDIX I}

\section{Study Instrument}

1. Name of Enterprise

2. Nature of Business

a. Organized b. Unorganized

3. How long have you been operating?

4. $\quad$ How long since you joined the Susu Scheme?

5. What is / are the sources of your initial capital?

\begin{tabular}{|ll|}
\hline a. & Personal Savings (Susu) \\
\hline b. & Relations \\
\hline c. & Bank Loan \\
\hline d. & Suppliers Credit \\
\hline e. & Profits \\
\hline f. & Customer Advances \\
\hline g. & A combination of the above \\
\hline
\end{tabular}

6. what is / are the sources of your working capital

\begin{tabular}{|ll|}
\hline a. & Personal Savings (Susu) \\
\hline b. & Relations \\
\hline c. & Bank Loan \\
\hline d. & Suppliers Credit \\
\hline e. & Profits \\
\hline f. & Customer Advances \\
\hline g. & A combination of the above \\
\hline
\end{tabular}

7. What was you capital before joining Susu ?

8. What is your capital now?

9. How many people did you employ before joining the Susu Scheme

10. How many people do now after Susu?

11. How has Susu been Helpful 


\section{APPENDIX II}

The Analysis of changes in Level of Employment and Total Turnover on Investment after Five years of involvement of any Susu Scheme (Organized Group)

\begin{tabular}{|c|c|c|c|c|c|}
\hline & $\begin{array}{c}\text { No Of Years In The } \\
\text { Business }\end{array}$ & $\begin{array}{c}\text { Employees Before } \\
\text { SUSU }\end{array}$ & $\begin{array}{c}\text { Employee } \\
\text { After Susu }\end{array}$ & $\begin{array}{l}\text { Annual Turnover } \\
\text { Before Susu (Av.) }\end{array}$ & $\begin{array}{c}\text { Annual Turnover } \\
\text { After Susu } 000 \text { (Av.) }\end{array}$ \\
\hline 1. & 8 & 6 & 8 & 547,500 & 146,000 \\
\hline 2. & 5 & & 2 & 14,450 & 300,000 \\
\hline 3. & 6 & 1 & & 273,350 & 547,500 \\
\hline 4. & 5 & 2 & 2 & 216,000 & 864,000 \\
\hline 5. & 10 & 3 & 4 & 182,500 & 365,000 \\
\hline 6. & & 3 to 5 & 8 & 324,000 & 432,000 \\
\hline 7. & 12 & 1 & 3 & 120,000 & 225,000 \\
\hline 8. & 7 & 1 to 11 & 1 to 13 & 30,000 & 80,000 \\
\hline 9. & 10 & 4 & 6 & 270,000 & 500,000 \\
\hline 10. & 15 & 2 & 2 & 146,000 & 292,000 \\
\hline 11. & 20 & 2 & 4 & 700,000 & $36,000,000$ \\
\hline 12. & 2 & 2 & 4 & 109,500 & 225,500 \\
\hline 13. & 7 & 1 & 2 & 203,760 & 547,500 \\
\hline 14. & & 1 & 1 & 300,000 & 474,500 \\
\hline 15. & 25 & 3 & 6 & 156,000 & 624,000 \\
\hline 16. & 8 & 2 & 2 & 108,000 & 130,000 \\
\hline 17. & & 1 & 2 & 36,500 & 219,000 \\
\hline 18. & 5 & 1 & 1 & 180,000 & 400,000 \\
\hline 19. & 6 & 2 & 2 & 255,500 & 780,000 \\
\hline 20. & 9 & 1 to 3 & 4 & 180,000 & 400,000 \\
\hline 21. & & 3 & 10 & 240,000 & 500,000 \\
\hline 22. & 3 & 6 & & 365,000 & 547,500 \\
\hline 23. & & 4 to 5 & 5 to 6 & 365,700 & 277,500 \\
\hline 24. & 18 & 3 & 3 & 182,500 & 547,500 \\
\hline 25. & 8 & 2 & 4 & 438,000 & 730,000 \\
\hline 26. & 10 & 1 & 5 & 182,500 & 480,000 \\
\hline 27. & 5 & 1 & 3 & 164,250 & 912,500 \\
\hline 28. & 7 & 2 & 5 & 146,000 & 474,500 \\
\hline 29. & 10 & 2 & & 18,250 & 328,500 \\
\hline 30. & & 2 & 2 & 328,500 & 620,500 \\
\hline 31. & 9 & 3 & 4 & 324911 & 655016 \\
\hline 32. & 3 & 1 & 3 & 213442 & 774523 \\
\hline 33. & 11 & 3 & 3 & 155432 & 964835 \\
\hline 34. & 7 & 3 & 4 & 334259 & 534780 \\
\hline 35. & 9 & 2 & 6 & 445,500 & 498,000 \\
\hline 36. & 11 & 4 & 9 & 342,000 & 240,000 \\
\hline 37. & 8 & 3 & 7 & 705,000 & 360,000 \\
\hline 38. & 6 & 2 & 8 & 460,000 & 200,000 \\
\hline 39. & 9 & 4 & 16 & 270,000 & 620,000 \\
\hline 40. & 8 & 3 & 7 & 120,000 & 240,000 \\
\hline 41. & 9 & 4 & 7 & 68,0000 & 186,000 \\
\hline
\end{tabular}


The Analysis of Small Scale Industries Financial Strength, Level of Employment,

And Number of Years Joining The Susu Group Before and After (Un-organized group)

\begin{tabular}{|c|c|c|c|c|c|}
\hline & $\begin{array}{c}\text { No Of Years In The } \\
\text { Business }\end{array}$ & $\begin{array}{c}\text { Employees Before } \\
\text { Susu }\end{array}$ & $\begin{array}{l}\text { Employee } \\
\text { After Susu }\end{array}$ & $\begin{array}{l}\text { Annual Turnover } \\
\text { Before Susu (Av.) }\end{array}$ & $\begin{array}{c}\text { Annual Turnover } \\
\text { After Susu } 000 \text { (Av.) }\end{array}$ \\
\hline 42. & 9 & 3 & 5 & 46,500 & $84,000,000$ \\
\hline 43. & 7 & 1 & 3 & 14,450 & $26,000,000$ \\
\hline 44. & 6 & 1 & 1 & 296,500 & $3,600,000$ \\
\hline 45. & 5 & 2 & 2 & 216,000 & $1,200,000$ \\
\hline 46. & 10 & 3 & 4 & 182,500 & 365,000 \\
\hline 47. & 9 & 3 & 5 & 104,000 & $3,280,000$ \\
\hline 48. & 6 & 1 & 4 & 120,000 & 225,000 \\
\hline 49. & 7 & 4 & 11 & 360,000 & $6,000,000$ \\
\hline 50. & 10 & 4 & 6 & 270,000 & 500,000 \\
\hline 51. & 13 & 2 & 2 & 143,000 & $92,000,000$ \\
\hline 52. & 15 & 2 & 4 & 700,000 & $6,000,000$ \\
\hline 53. & 6 & 1 & 4 & 117,500 & $2,200,500$ \\
\hline 54. & 11 & 1 & 3 & 228,760 & $5,500,000$ \\
\hline 55. & 6 & 1 & 1 & 30,000 & 560,500 \\
\hline 56. & 12 & 0 & 3 & 156,000 & $1,600,000$ \\
\hline 57. & 8 & 1 & 5 & 180,000 & $5,800,000$ \\
\hline 58. & 17 & 1 & 6 & 66,500 & $6,200,000$ \\
\hline 59. & 5 & 1 & 3 & 30,000 & 400,000 \\
\hline 60. & 6 & 2 & 2 & 255,500 & 780,000 \\
\hline 61. & 9 & 1 to 3 & 4 & 180,000 & 400,000 \\
\hline 62. & & 3 & 10 & 240,000 & 500,000 \\
\hline 63. & 7 & 6 & 6 & 365,000 & $5,600,500$ \\
\hline 64. & 6 & 4 & 5 & 65,700 & $10,700,500$ \\
\hline 65. & 14 & 3 & 4 & 182,500 & $3,000,000$ \\
\hline 66. & 8 & 2 & 5 & 400,000 & $2,000,000$ \\
\hline 67. & 10 & 1 & 5 & 800,000 & $6,000,000$ \\
\hline 68. & 5 & 1 & 3 & 160,000 & 900,000 \\
\hline 69. & 6 & 2 & 5 & 150,000 & 500,000 \\
\hline 70. & 10 & 2 & 8 & 200,000 & $3,500,000$ \\
\hline 71. & 8 & 1 & 4 & 300,000 & $4,800,000$ \\
\hline 72. & 7 & 3 & 4 & 450,000 & $6,500,000$ \\
\hline 73. & 3 & 1 & 3 & 250,000 & $1,800,000$ \\
\hline 74. & 11 & 2 & 2 & 90,000 & $2,000,000$ \\
\hline 75. & 7 & 3 & 4 & 50,00 & 500,000 \\
\hline 76. & 9 & 2 & 6 & 400,000 & $1,200,000$ \\
\hline 77. & 11 & 4 & 9 & 200,000 & $2,400,000$ \\
\hline 78. & 8 & 3 & 7 & 70,000 & 360,000 \\
\hline 79. & 6 & 2 & 8 & 600,000 & $3,000,000$ \\
\hline 80. & 12 & 4 & 7 & 270,000 & 620,000 \\
\hline 81. & 8 & 3 & 5 & 120,000 & 240,000 \\
\hline 82. & 9 & 1 & 1 & 300,000 & $1,800,000$ \\
\hline 83. & 7 & 3 & 4 & 250,000 & $6,500,000$ \\
\hline 84. & 3 & 1 & 1 & 120,000 & 800,000 \\
\hline 85. & 11 & 2 & 2 & 90,000 & $1,800,000$ \\
\hline 86. & 7 & 1 & 3 & 150,00 & $2,500,000$ \\
\hline 87. & 9 & 2 & 4 & 600,000 & $3,000,000$ \\
\hline 88. & 11 & 0 & 3 & 200,000 & $2,400,000$ \\
\hline 89. & 8 & 1 & 2 & 70,000 & $5,000,000$ \\
\hline 90. & 6 & 2 & 8 & 600,000 & $3,000,000$ \\
\hline 91. & 11 & 3 & 5 & 270,000 & $1,600,000$ \\
\hline 92. & 8 & 2 & 4 & 120,000 & $2,400,000$ \\
\hline 93. & 9 & 1 & 1 & 300,000 & $1,800,000$ \\
\hline 94. & 6 & 2 & 5 & 500,000 & $6,000,000$ \\
\hline 95. & 7 & 0 & 3 & 600,000 & $7,000,000$ \\
\hline 96. & 5 & 2 & 3 & 800,000 & $4,000,000$ \\
\hline 97. & 12 & 4 & 6 & 400,000 & $3,000,000$ \\
\hline 98. & 8 & 1 & 3 & 250,000 & $6,000,000$ \\
\hline 99. & 10 & 3 & 6 & 500,000 & $8,000,000$ \\
\hline 100. & 11 & 2 & 4 & 40,000 & $1,200,000$ \\
\hline 101. & 6 & 1 & 3 & 100,000 & $2,600,000$ \\
\hline
\end{tabular}


Composite analysis for changes in employment

\begin{tabular}{|c|c|}
\hline sum & 218 \\
\hline $\mathrm{n}$ & 97 \\
\hline mean & 2.247 \\
\hline stdev & 2.031168218 \\
\hline st. error & 0.206233212 \\
\hline test statistic & 10.89748184 \\
\hline critical & 2.33 \\
\hline
\end{tabular}

Reject ho

\section{Composite analysis for changes in total Turnover on investment}

\begin{tabular}{|c|c|}
\hline sum & $401,221,440$ \\
\hline $\mathrm{n}$ & 101 \\
\hline mean & $3,972,489.505$ \\
\hline stdev & 12866078.15 \\
\hline st. error & 1280334.178 \\
\hline test statistic & 3.102697385 \\
\hline critical & 2.33 \\
\hline
\end{tabular}

Reject ho

Analysis if Differentials Changes in employment for organized

\begin{tabular}{|c|c|}
\hline sum & 54 \\
\hline $\mathrm{n}$ & 32 \\
\hline mean & 1.688 \\
\hline stdev & 1.654661061 \\
\hline st. error & 0.292503148 \\
\hline test statistic & 5.769168669 \\
\hline critical & 2.33 \\
\hline
\end{tabular}

Reject ho

\section{Analysis if Differentials Changes in employment for organized}

\begin{tabular}{|l|r|}
\hline sum & $44,038,850$ \\
\hline $\mathrm{n}$ & 36 \\
\hline mean & $1,223,301.389$ \\
\hline stdev & 5846297.564 \\
\hline st. error & 974382.9274 \\
\hline test statistic & 1.255462667 \\
\hline critical & 2.33 \\
\hline accept ho & \\
\hline
\end{tabular}

\section{Analysis if Differentials Changes in employment for Unorganized}

\begin{tabular}{|l|r|}
\hline sum & 164 \\
\hline $\mathrm{n}$ & 65 \\
\hline mean & 2.523 \\
\hline stdev & 2.151363611 \\
\hline st. error & 0.266852346 \\
\hline test statistic & 9.454955013 \\
\hline critical & 2.33 \\
\hline Reject ho & \\
\hline
\end{tabular}


Analysis if Differentials Changes in Turnover for Unorganized

\begin{tabular}{|c|c|}
\hline sum & $357,182,590$ \\
\hline $\mathrm{n}$ & 65 \\
\hline mean & $5,495,116.769$ \\
\hline stdev & 15275869.45 \\
\hline st. error & 1894728.484 \\
\hline test statistic & 2.900213311 \\
\hline critical & 2.33 \\
\hline Reject ho & \\
\hline
\end{tabular}

\section{NOTES}




\section{NOTES}

